\title{
PtSRR1, A PUTATIVE PISOLITHUS TINCTORIUS SYMBIOSIS RELATED RECEPTOR GENE IS EXPRESSED DURING THE FIRST HOURS OF MYCORRHIZAL INTERACTION WITH CASTANEA SATIVA ROOTS
}

\author{
B. Acioli-Santos ${ }^{1,2,3, *}$; E. Malosso ${ }^{1}$; C. E. Calzavara-Silva ${ }^{2}$; C. E. P. Lima ${ }^{1}$; A. Figueiredo ${ }^{3}$; M. Sebastiana ${ }^{3}$; M. S. Pais ${ }^{3}$ \\ ${ }^{1}$ Departamento de Micologia, Universidade Federal de Pernambuco, Recife, PE, Brasil; ${ }^{2}$ Centro de Pesquisas Aggeu Magalhães, \\ Fundação Instituto Oswaldo Cruz, Departamento de Virologia e Terapia Experimental-LaViTE, Universidade Federal de \\ Pernambuco, Recife, PE, Brasil; ${ }^{3}$ Unit of Molecular Biology and Plant Biotechnology, ICAT, Faculdade de Ciências de Lisboa, \\ Universidade de Lisboa, Lisboa, Portugal.
}

Submitted: May 20, 2008; Returned to authors for corrections: September 27, 2008; Approved: March 31, 2009.

\begin{abstract}
PtSRR1 EST was previously identified in the first hours of Pisolithus tinctorius and Castanea sativa interaction. QRT-PCR confirmed PtSRRI early expression and in silico preliminary translated peptide analysis indicated a strong probability that $P t S R R I$ be a transmembrane protein. These data stimulate the PtSRRI gene research during ectomycorrhiza formation.
\end{abstract}

Key words: ectomycorrhiza, symbiosis related genes/proteins, Pisolithus tinctorius.

The formation of ectomycorrhiza is a process governed by a complex biochemical and molecular interaction between the two partners before physical contact. Several stages of the ectomycorrhiza formation and maintenance processes from preinfection to the formation of the mantle and the Hartig net have been described, and it is obvious that changes in gene expression have to accompany the processes leading to symbiosis $(6,8)$.

Studies evaluating the fungal transcript pattern during symbiosis formation have demonstrated that mycorrhization induces changes in the expression of genes normally expressed in the free organisms, without the participation of symbiosis specific genes (9). In this paper, we present a fungal cDNA EST representing a gene that is upregulated at $12 \mathrm{~h}$ of interaction between $P$. tinctorius and $C$. sativa (1). Its expression, the putative protein structure and its possible function in the symbiosis are discussed.

Biological material acquisition/maintenance and ectomicorrhizal induction is described by Baptista et al. (2007) (2). Micohhiza stimulated ("myc") and control mycelium (only in water) were harvested $12 \mathrm{~h}$ after contact, snap-frozen in liquid nitrogen and stored at $-80^{\circ} \mathrm{C}$. A cDNA library of $P$. tinctorius was constructed from $6 \mu \mathrm{g}$ of mRNA mix (control and "myc") using the SMART cDNA Library Construction Kit (BD Clontech, Palo Alto, CA, U.S.A) as presented by Acioli-Santos et al. (2008). For the quantification of the PtSRRI mRNAs, the reverse transcription of each target RNA (control RNA and "myc" at $6 \mathrm{~h}$ and $12 \mathrm{~h}$ of interaction) was carried out (7).

The cloned PtSRRI EST fragment is 432 bp long. An untranslated region is observed downstream from the putative open reading frame (Fig. 1). The PtSRRI sequence has 70\% similarity to a sequence of Pisolithus microcarpus (CB010071), a fungus that forms ectomycorrhiza with Eucalyptus. The putative PtSRRI peptide has $48 \%$ similarity to a protein of the fungus Schizophyllum commune (AF335537) that is upregulated under low nitrogen conditions. The study of the PtSRRI expression using QRT-PCR allowed the confirmation of the upregulation at $12 \mathrm{~h}$ of interaction, revealing positive transcription rates 1350 fold higher than the control. At $6 \mathrm{~h}$ of fungus-plant interaction, the relative values were close to one, suggesting that changes in the transcription levels may occur between 6 and $12 \mathrm{~h}$ of interaction.

In silico translation of PtSRRI nucleotide sequence resulted in a peptide fragment of 75 amino acids $(8.2 \mathrm{kDa})$, without the

*Corresponding Author. Mailing address: Departamento de Micologia, Universidade Federal de Pernambuco. Av. Prof. Nelson Chaves s/n, Cidade Universitária. 50670-420, Recife, PE, Brasil. Phone: +55 812126 8865. Fax: +55 81 21268482. E-mail: bartacioli@cpqam.fiocruz.br 


\begin{tabular}{|c|c|c|c|c|c|c|c|c|c|c|c|c|c|c|c|c|}
\hline 1 & AGT & CGT & CTG & GGA & CAC & GAG & TAC & GCC & $\mathrm{CCT}$ & GCA & CAA & ATC & TCA & $\mathrm{AAT}$ & $\mathrm{TCA}$ & 45 \\
\hline 1 & S & R & L & G & $\mathrm{H}$ & $E$ & Y & A & P & A & Q & I & S & $\mathrm{N}$ & S & 15 \\
\hline 46 & GAG & GGA & CAG & $\mathrm{ATT}$ & TAT & СТC & GTC & GTA & $A A C$ & $\mathrm{AAC}$ & СTC & ATC & GAT & TTC & GAC & 90 \\
\hline 16 & $\mathrm{E}$ & G & Q & I & Y & L & V & V & $\mathrm{N}$ & $\mathrm{N}$ & L & I & D & F & $\mathrm{D}$ & 30 \\
\hline 91 & TAC & TTG & TTG & GCA & AAT & GAT & TTC & $\mathrm{AAT}$ & ATT & $\mathrm{CTC}$ & GAT & GGG & AGT & GTG & ATG & 135 \\
\hline 31 & Y & L & L & A & $\mathrm{N}$ & D & F & $\mathrm{N}$ & I & L & D & G & S & V & M & 45 \\
\hline 136 & GTC & $\mathrm{ACA}$ & GTA & $\mathrm{CCG}$ & GAC & GTG & $\mathrm{CCG}$ & $\mathrm{ACT}$ & GGC & $\mathrm{ATT}$ & TAT & $\mathrm{GCC}$ & ATC & GTC & TTG & 180 \\
\hline 46 & V & $\mathrm{T}$ & V & $\mathrm{P}$ & D & V & P & $\mathrm{T}$ & G & I & $Y$ & A & I & V & L & 60 \\
\hline 181 & TTT & GGT & GAT & TCT & GGT & $A A C$ & TTT & AGC & $\mathrm{CAG}$ & $A A C$ & TTC & $\mathrm{AC} \mathrm{C}$ & ATC & ATA & $\mathrm{GCG}$ & 225 \\
\hline 61 & F & G & D & S & G & $\mathrm{N}$ & F & S & Q & $\mathrm{N}$ & $\mathrm{F}$ & $\mathrm{T}$ & I & I & A & 75 \\
\hline $\begin{array}{l}226 \\
76\end{array}$ & $\begin{array}{c}\text { TGA } \\
\star\end{array}$ & TCC & CAT & CAC & GTC & $\mathrm{CTT}$ & $\mathrm{GCA}$ & $\mathrm{ACT}$ & TTA & $\mathrm{TCT}$ & CTC & TGA & $A C G$ & $\mathrm{ATT}$ & $\mathrm{TCA}$ & 270 \\
\hline 271 & TGA & $A C A$ & $\mathrm{ATG}$ & ATG & $A A G$ & GAC & TTC & TGT & TTC & GTT & TAC & $\mathrm{CAC}$ & $\mathrm{TCA}$ & GGA & CTT & 315 \\
\hline 316 & GGT & TTC & ATA & $\mathrm{CAT}$ & TAG & GAC & GAC & AAA & TAC & $\mathrm{AAT}$ & $\mathrm{GCA}$ & TCC & GGA & $\mathrm{ACA}$ & TTT & 360 \\
\hline 361 & AGC & $\mathrm{AAT}$ & GGA & CTT & GTA & $\mathrm{ACC}$ & $\mathrm{CCC}$ & TTT & CGC & $\mathrm{ATT}$ & CTG & CTG & TAC & GTA & TAT & 405 \\
\hline 406 & GGA & CTA & GGA & TCC & GGG & $\mathrm{ACC}$ & $\mathrm{ATT}$ & CTA & CTA & \multicolumn{2}{|c|}{432} & & & & & \\
\hline
\end{tabular}

Figure 1. The PtSRRI EST: nucleotide sequence ( $432 \mathrm{bp)}$ ) and partial ORF (leters below the codons, totalling 75 aminoacids). The termination codon is assigned with an asterisc. The partial ORF was identified using MapDraw (Informatik Inc. USA) and represents the largest translation region for the sequence.

initial methionine. No cysteine residues were found in the PtSRR1 amino acid sequence. The analyses of the PtSRR1 peptide primary structure (http://ca.expasy.org/cgi-bin/prosite) enabled the identification of four post-translational modification sites as follows: two N-glycosylation sites with high probability of occurrence between the residues 66 to 69 (NFSQ) and 70 to 73 (NFTI), and two Casein Kinase II phosphorylation sites, in the positions 13 to 16 (SNSE) and 47 to 50 (TVPD), respectively (Fig. 2a). No usual protein domais were identified. Secondary PtSRRl structure analisys showed abundance of betastructures (Fig. 2a). No helix was detected. The peptide shows a well-defined transmembrane region, despite the low probability suggested by its analysis (http://www.predictprotein.org). It was not possible to obtain a PtSRR1 three-dimensional model based on homology modeling (http://www.swissmodel.expasy.org/ SWISS-MODEL.html) (Fig. 2b).

The expression of several genes at $6 \mathrm{~h}$ of interaction between Laccaria bicolor and Pinus resinosa has been reported $(4,5)$. However, most of the differentially expressed fungal genes were observed in later stages of symbiotic development, especially after two or more days of interaction $(3,6,9)$, which is corroborated by the $12 \mathrm{~h}$ PtSRRI transcription. Therefore, the high relative expression of PtSRRI at $12 \mathrm{~h}$ favours its investigation. QRT-PCR data confirmed the cDNA microarrays analysis of the fungal PtSRRl and its high relative transcription at $12 \mathrm{~h}$ of ectomycorrhizal interaction. Transcription of this gene does not occur until $6 \mathrm{~h}$ of contact, suggesting that this period between 6 and $12 \mathrm{~h}$ can be critical for its expression.

The PtSRRI gene is that probably triggered by the low availability of nitrogen that could function as an "indicator" of host root proximity. PtSRRI homologue peptide (AF335537) was identified in Schizophyllum commune. This homologue peptide presents high expression when the mycelium is growing under low nitrogen availability conditions. Further physiological studies and the acquisition of the complete ORF of this gene are necessary for functionality tests in the symbiosis. These results would allow to understand the real function of the PtSRR1 protein.

As the PtSRRI amino acid sequence is not complete and the three-dimensional protein structure is not known, any conclusion about the role of this protein is premature. However, considering its secondary structure prediction, the PtSRRI 


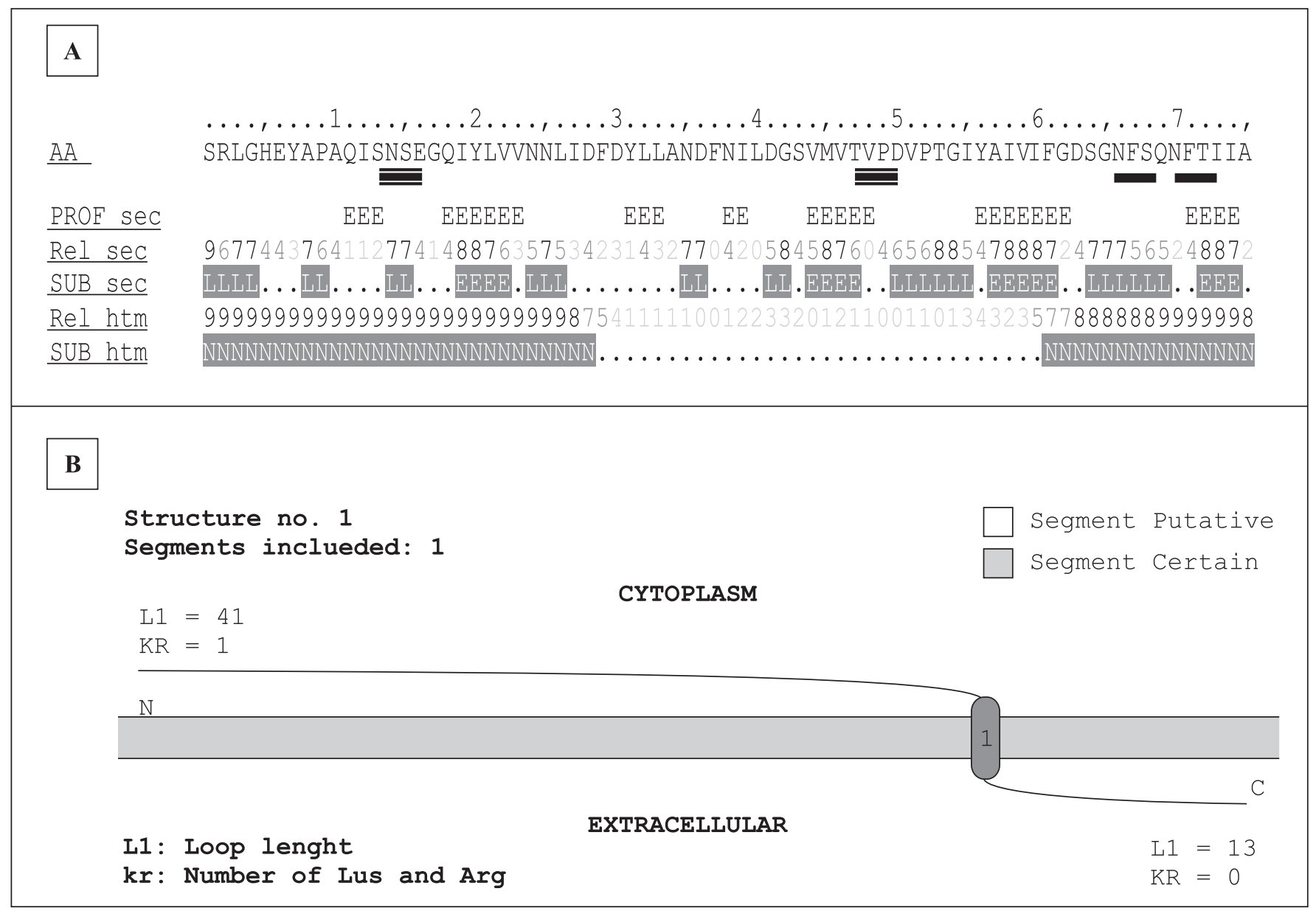

Figure 2. PtSRRI in silico analysis. A) The sequence of the 75 amino acid residues. AA = amino acid sequence. Triple and single lines below the amino acid sequence indicate the phosphorylation and glycosylation sites, respectively. PROF_sec $=$ PROF predicted secondary structure: $\mathrm{H}=$ helix, $\mathrm{E}=$ extended (sheet), blank = other (loop), Rel_sec = reliability index for PROFsec prediction $(0=$ low to $9=$ high $)$, SUB_sec $=$ subset of the PROFsec prediction. For this subset the following symbols are used: L is loop, E is extended (sheet), and "." means that no prediction is made for this residue as the reliability is Rel $<5$, Rel_htm = reliability index for PHDhtm (not shown) prediction $(0=$ low to $9=$ high), SUB_htm $=$ subset of the PHDhtm prediction (not shown), $\mathrm{N}$ is non-membrane region, "." means that no prediction is made for this residue as the reliability is Rel $<7$. B) The putative transmembrane region of PtSRRI. Note the cytoplasmic region larger than extracellular segment of the protein.

seems to be a transmembrane protein with an intracellular segment containing at least one phosphorylation accessible site and an extracellular region containing two glycosylation sites. Thus, there is a possibility that the PtSRRI acts as membrane receptor/extra-intracellular signal-transducer element through sites of glycosylation and phosphorylation, or be a secreted protein. However, in silico data obtained using the truncated PtSRRI amino acid sequence would differ from the full-length amino acid sequence. These data strongly stimulate the research of PtSRRI gene role in the ectomycorrhizal process as a potential marker/regulator of the early stages of symbiotic interaction.

\section{ACKNOWLEDGEMENTS}

This work was partially supported by CAPES (Coordenação de Aperfeiçoamento de Pessoal de Nível Superior/MCT-Brazil) as a Ph.D. scholarship and grant to the first author. 


\section{RESUMO}

\section{PtSRR1, um possível receptor simbiose-regulado de Pisolithus tinctorius é expresso nas primeiras horas de interação ectomicorrízica com raízes de Castanea sativa}

PtSRR1 foi isolado preliminarmente de P. tinctorius nas primeiras horas da interação com raízes de $C$. sativa. Análises de QRT-PCR confirmaram sua expressão positiva (12 h) e seu peptídeo putativo indicou forte possibilidade para proteína transmembranar. Estes dados estimulam o estudo do PtSRRI durante a formação de ectomicorrizas.

Palavras-chave: ectomicorriza, genes/proteínas simbioseregulados, Pisolithus tinctorius.

\section{REFERENCES}

1. Acioli-Santos, B.; Sebastiana, M.; Pessoa, F.; Sousa L.; Figueiredo, A.;Fortes, A.M.; Baldé, A.; Maia, L.C.; Pais, M.S. (2008). Fungal transcript pattern during the preinfection stage $(12 \mathrm{~h})$ of ectomycorrhiza formed between pisolithus tinctorius and castanea sativa roots, identified using cdna microarrays. Curr. Microbiol. (In press)
2. Baptista, P.; Martins, A.; Pais, M.S.; Tavares, R.M.; Lino-Neto, T. (2007). Involvement of reactive oxygen species during early stages of ectomycorrhiza establishment between Castanea sativa and Pisolithus tinctorius. Mycorrhiza, 17, 185-193.

3. Duplessis, S.; Courty, P.; Tagu, D.; Martin, F. (2005).Transcript patterns associated with ectomycorrhiza development in Eucalyptus globulus and Pisolithus microcarpus. New Phytol., 165, 599-611.

4. Kim, S.; Bernreuther, D.; Thumm, M.; Podila, G. (1999). LB-AUT7, a novel symbisis-regulated gene from an ectomycorrhizal fungus, Laccaria bicolor, is functionally related to vesicular transport and autophagocytosis. J. Bacteriol., 181, 1963-1967.

5. Kim, S.; Zheng, J.; Hiremath, T.; Podila, G.K. (1998). Cloning and characterization of a symbiosis-related gene from an ectomycorrhizal fungus Laccaria bicolor. Gene, 222, 203-212.

6. Le Quéré, A.; Wright, D.P.; Söderström, B.; Tunlid, A.; Johansson, T. (2005). Global patterns of gene regulation associated with the development of ectomycorrhiza between Birch (Betula pendula Roth.) and Paxillus involutus. Mol. Plant-Microbe Interact., 18, 659-673.

7. Santos, B.A. (2006). Expressão gênica no fungo Pisolithus tinctorius em etapas iniciais da interação ectomicorrízica com Castanea sativa: estudo do padrão de transcrição e de possíveis fatores de regulação da simbiose. Tese de Doutorado. Lisboa, 169 p. (Ph. D., Departamento de Biologia Vegetal, Universidade de Lisboa).

8. Tagu, D.; Lapeyrie, F.; Martin, F. (2002). The ectomycorrhizal symbiosis: genetics and development. Plant Soil, 244: 97-105.

9. Voiblet, C.; Duplessis, S.; Encelot, L.; Martin, F. (2001). Identifications of symbiosis-reguleted genes in Eucalyptus globulus-Pisolitus tinctorius ectomycorrhiza by differential hybridization of arrayed cDNAs. Plant. $J ., 25,181-191$ 